\title{
Bottlenecks in the PGRFA use system: stakeholders' perspectives
}

\author{
Shelagh Kell $\cdot$ Mario Marino $\cdot$ Nigel Maxted
}

Received: 15 January 2017 / Accepted: 22 June 2017 / Published online: 11 July 2017

(C) The Author(s) 2017. This article is an open access publication

\begin{abstract}
An essential component of efforts to mitigate the impacts of climate change on crop production and food security is the production of new varieties of crops which can thrive in more extreme, changeable and uncertain environmental conditions. Humankind is therefore dependent on the continual availability of a wide pool of plant genetic resources for food and agriculture (PGRFA) to sustain our food and economic security, yet despite the vast pool of resources that exists, we face significant hurdles in mobilizing them for effective and sustainable use. The Governing Body
\end{abstract}

This article is part of the Topical Collection on Plant Breeding: the Art of Bringing Science to Life. Highlights of the 20th EUCARPIA General Congress, Zurich, Switzerland,

29 August-1 September 2016

Edited by Roland Kölliker, Richard G. F. Visser, Achim Walter \& Beat Boller

Electronic supplementary material The online version of this article (doi:10.1007/s10681-017-1935-z) contains supplementary material, which is available to authorized users.

S. Kell $(\bowtie) \cdot$ N. Maxted

School of Biosciences, University of Birmingham,

Edgbaston, Birmingham B15 2TT, UK

e-mail: s.kell@bham.ac.uk

M. Marino

FAO, International Treaty on Plant Genetic Resources for Food and Agriculture, Viale delle Terme di Caracalla 1, 00153 Rome, Italy of the International Treaty on Plant Genetic Resources for Food and Agriculture (the Treaty) has recognized the pivotal role of sustainable use of PGRFA in addressing global challenges-including climate change adaptation, food security and biodiversity loss-and the need to assist countries in designing measures to promote the sustainable use of PGRFA. A global survey was conducted by the Secretariat of the Treaty to gather the views and needs of PGRFA stakeholders, the results of which have allowed a clearer understanding of the 'bottlenecks' in the PGRFA use system and a deeper comprehension of the constraints and needs regarding the implementation of the sustainable use provisions of the Treaty. In particular, there is a critical need to address: (a) limitations regarding policy in support of sustainable use activities; (b) capacity building needs in all areas of the PGRFA sustainable use spectrum; and (c) access to plant genetic material and associated information.

Keywords Genetic resources - Plant genetic resources for food and agriculture $\cdot$ Sustainable use . Climate change adaptation - Food security . International Treaty on Plant Genetic Resources for Food and Agriculture - PGRFA stakeholders · Stakeholder survey 


\section{Introduction}

The impacts of climate change on crop production and food security are widely acknowledged. An essential component of efforts to mitigate these impacts is the production of new varieties of crops which can thrive in more extreme, changeable and uncertain environmental conditions. The Intergovernmental Panel on Climate Change (IPCC) highlighted that the risks of crop production shortfalls at the high range of projected temperature changes may only be reduced through plant breeding aimed at increasing yield potential and drought resistance, along with altered agronomic management practices (Olesen et al. 2011; Rötter et al. 2011; Ventrella et al. 2012; Kovats et al. 2014) and placed the development of new crop varieties at the top of a list of technological adaptation options (Noble et al. 2014). Furthermore, the development of new cultivars has been found to be the most effective modification to improve crop yields in a range of climate change and adaptation scenarios (Challinor et al. 2014). Given the problem of increased climate variability, the IPCC also emphasized the need for greater use of between (as well as within) species genetic diversity in farming systems, placing even greater emphasis on the need to conserve and make available a broad range of plant genetic diversity both within and between species to maximize options for the continued development of a wide range of crop species as an insurance against climate variability (Kovats et al. 2014). Plant breeders are therefore in need of a continuous supply of diverse and novel genetic diversity to produce new crop varieties able to cope with the impacts of changing cultivation conditions (FAO 2008; Guarino and Lobell 2011; Luck et al. 2011; Maxted et al. 2012; McCouch et al. 2013). A vast pool of this diversity exists in nature, in production systems and in genebanks, and the PGRFA community has the knowledge, tools, techniques and rapidly evolving technology to conserve and use these genetic resources wisely to sustain crop production. However, as highlighted by FAO (2010), there is a range of complex issues causing significant limitations to the effective management and availability of PGRFA which is resulting in loss and inefficient utilization of diversity-diversity that constitutes an untapped resource which could support the plant breeding and agricultural industries and prove critical for future food security.
The International Treaty on Plant Genetic Resources for Food and Agriculture (ITPGRFA-the Treaty) is a legally binding instrument with the objectives of facilitating conservation and sustainable use of PGRFA and the fair and equitable sharing of benefits derived from their use, in harmony with the Convention on Biological Diversity (CBD). The Treaty defines PGRFA as "any genetic material of plant origin of actual or potential value for food and agriculture", genetic material being "any material of plant origin, including reproductive and vegetative propagating material, containing functional units of heredity". PGRFA include cultivated varieties of plant species (landraces and modern cultivars), wild plant species with potential as trait donors to crops (crop wild relatives-CWR), wild-harvested species used for human and animal food, and plant breeders' material—advanced lines, élite varieties and DNA. Specifically with regard to conservation and sustainable use, the primary targets are those PGRFA that are threatened by: (a) under-use or abandonment (many landraces/farmers' varieties, as well as neglected and underutilized species — or 'orphan crops'); (b) a range of primarily human-induced threats, including the wide-ranging and unpredictable impacts of climate change, agricultural intensification, land-use transformation, habitat destruction, and pollution-factors which may affect in situ populations of wild and cultivated PGRFA; and (c) over-use (many wildharvested species and some CWR).

The Governing Body of the Treaty has recognized the pivotal role of sustainable use of PGRFA in addressing global challenges, including climate change adaptation, food security, poverty alleviation and biodiversity loss. The implementation of Article 6 of the Treaty, 'Sustainable Use of Plant Genetic Resources ${ }^{1}$ is a standing priority item on the agenda of the Governing Body with the aim of promoting an integrated approach to the sustainable use of PGRFA among Contracting Parties. Under Article 6.1, Contracting Parties are required to "develop and maintain appropriate policy and legal measures that promote the sustainable use of plant genetic resources for food and agriculture", while Article 6.2 lists examples of measures for the sustainable use of PGRFA:

\footnotetext{
${ }^{1}$ www.fao.org/plant-treaty/areas-of-work/sustainable-use/overview/ en/.
} 
(a) Pursuing fair agricultural policies that promote, as appropriate, the development and maintenance of diverse farming systems that enhance the sustainable use of agricultural biological diversity and other natural resources;

(b) Strengthening research which enhances and conserves biological diversity by maximizing intra- and inter-specific variation for the benefit of farmers, especially those who generate and use their own varieties and apply ecological principles in maintaining soil fertility and in combating diseases, weeds and pests;

(c) Promoting, as appropriate, plant breeding efforts which, with the participation of farmers, particularly in developing countries, strengthen the capacity to develop varieties particularly adapted to social, economic and ecological conditions, including in marginal areas;

(d) Broadening the genetic base of crops and increasing the range of genetic diversity available to farmers;

(e) Promoting, as appropriate, the expanded use of local and locally adapted crops, varieties and underutilized species;

(f) Supporting, as appropriate, the wider use of diversity of varieties and species in on-farm management, conservation and sustainable use of crops and creating strong links to plant breeding and agricultural development in order to reduce crop vulnerability and genetic erosion, and promote increased world food production compatible with sustainable development; and

(g) Reviewing, and, as appropriate, adjusting breeding strategies and regulations concerning variety release and seed distribution.

Recognizing that in many regions the implementation of Article 6 is lagging behind in comparison with other elements of the Treaty, the Governing Body proposed the development of a toolbox to assist countries in designing measures to promote the sustainable use of PGRFA. To understand the constraints affecting the capacity of national programmes and their specific needs regarding this toolbox, a global survey was conducted to gather the views of stakeholders in the PGRFA use system-a system that starts with wild and domesticated PGRFA, involves conservation, crop improvement and seed delivery systems, ultimately results in the harvesting and marketing of crop produce, and involves the full suite of stakeholders. Figure 1 shows the main elements of the system and the potential interactions between them. The system involves the use of PGRFA in both formal and informal seed systems and in the public and private sectors.

As indicated by Fig. 1, for PGRFA to be available for sustainable use, they have to be actively conserved. This may be in situ-either on-farm or in-garden for domesticated species, or in genetic reserves for wild species-or ex situ in genebanks. At this stage in the system, there may be flow between in situ conserved germplasm into genebanks and in some cases there may also be involvement of genebanks in in situ conservation. This may either be by working with farmers to repatriate conserved germplasm (e.g., in the Scottish Landrace Protection Scheme-Green 2008;

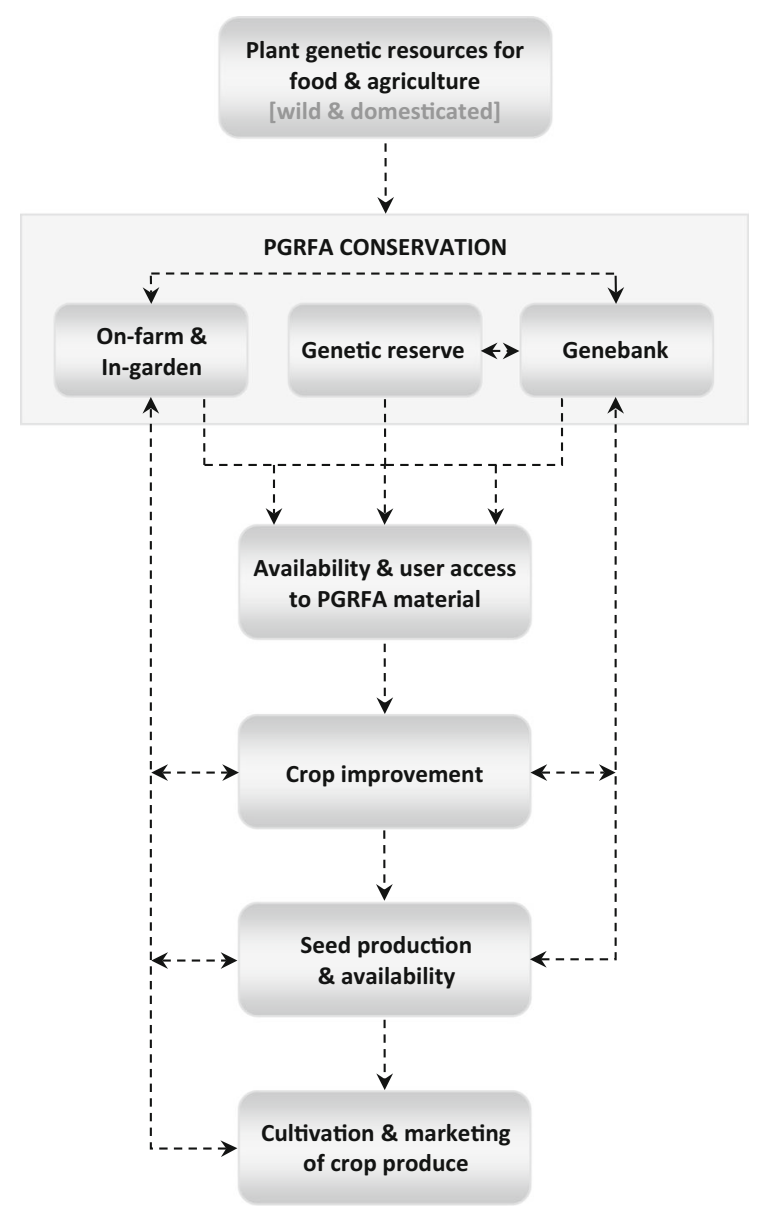

Fig. 1 The main elements of the PGRFA use system and the potential interactions between them 
Green et al. 2009), through their direct involvement in the establishment and management of CWR genetic reserves (e.g., see Pinheiro de Carvalho et al. 2012; Phillips et al. 2016), or by acting as a conduit between in situ conserved populations and germplasm users through regular collection of representative samples (Maxted et al. 2015, 2016)-for example, as illustrated by the National Gene Bank for German Crop Wild Relative Species. ${ }^{2}$ Although there is currently limited involvement of genebanks in these activities, it is important to acknowledge that this type of interaction does occur and that, given appropriate resources, it could become more prevalent in future. The next stage in the system is the availability of and accessibility to PGRFA material. The figure indicates the potential for flow of material from conserved sources to make it available and accessible to users. From here, the material is used for crop improvement, which may involve research, pre-breeding, breeding and/or selection, both in the public and private sectors and by farmers and other maintainers of crop diversity. In many countries, for crop varieties to enter into agriculture, they must be tested to ensure they meet the standards for registration (Distinctiveness, Uniformity and Stability_DUS) and performance (Value for Cultivation and Use-VCU), after which they are approved for commercial release, listed in a variety register, and certified seed is produced for the market. The improved varieties, whether produced by commercial breeders or farmers, are then dispersed through the seed system. This may involve commercial seed companies, or the informal seed system in which farmers and other maintainers may conserve and exchange material without going through the formal channels of crop variety testing, registration and seed certification. Finally, the improved crop varieties are cultivated and the produce marketed, except in the case of subsistence growers.

Importantly, the arrows on the left side of Fig. 1 show the potential and inherent links between farmers and other maintainers of PGRFA on-farm and ingarden, and other elements of the system. Farmers frequently undertake crop improvement on-farm through a process of selection and/or breeding, and they may be involved in participatory plant breeding in partnership with research institutes or private breeding

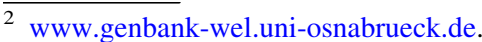

companies. The two-way arrow here indicates the important role played by farmers at this stage of the system and the benefits that farmers may gain from crop improvement. Likewise, farmers may be involved in seed production and in making it available to other growers, either through local markets or some form of exchange. As for the crop improvement stage, farmers may also benefit from the seed produced and either sold by private companies or made available by government bodies. And finally, farmers and other growers are inherently involved in cultivation and usually in some form of marketing of produce, whether for commercial gain or local distribution and exchange of goods. Thus, they make the produce available to the consumers and benefit from the utilization and/or sale of the produce. In addition, on the right side of the figure, the arrows indicate the potential roles of genebanks in the crop improvement process, particularly in research and pre-breeding, as well as the possibility for flow of material resulting from these activities into genebanks for wider distribution. Likewise, in some cases, genebanks may be involved in the multiplication and distribution of seed for use by farmers and other maintainers. Although the direct involvement of genebanks in these activities is not extensive, its existence should be acknowledged and their role may become more common in future. Furthermore, since many genebanks are integral to larger research or plant breeding institutes, it is somewhat artificial to separate them from these activities.

\section{Methods}

The stakeholder survey was conducted online in three languages (English, Spanish and French) using the SurveyMonkey platform ${ }^{3}$ and was made available in PDF format for respondents wishing to formulate answers on behalf of a collegiate group or network. The survey comprised four sections (Table 1; Supplementary File S1). Sections 2-4 included both mandatory (e.g., multiple choice and ranking) questions and optional questions in which respondents were requested to either substantiate their answers or to provide additional details. A pilot survey was

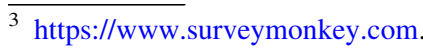


Table 1 Survey design

Section Information gathered

1. Stakeholder identification

2. Strengths and weaknesses of the current PGRFA use system

3. Constraints and needs regarding the implementation of PGRFA sustainable use strategies

4. Types and contents of resources required in the Toolbox
The purpose of this section was to verify the stakeholder groups with an interest in sustainable use of PGRFA and in the development of the Toolbox, and to identify their specific roles and/or interests in sustainable use, in order to tailor the Toolbox to their needs. To assess the representativeness of the survey results in terms of geographic range and to identify any potential regional variation with regard to stakeholders' needs, respondents identified the countries in which they work, as well as the geographic scale at which they operate (national and/or regional and/or global).

The objective of this section was to identify where the perceived bottlenecks are in the current PGRFA use system in order that the Toolbox can be designed to place emphasis on providing the support required by stakeholders in these specific areas.

The intention of this section was to pinpoint the specific constraints faced by stakeholders in implementing sustainable use strategies to aid the identification of the types of tools and resources that are needed to help overcome them. Potential constraints and needs were explored in three areas: (i) national policy in support of sustainable use of PGRFA; (ii) capacity building needs in order to implement the sustainable use provisions of the Treaty; and (iii) access to PGRFA material or associated information required for sustainable use. The data gathered in this section were also used to indicate whether there are any evident associations between constraints and needs according to the different stakeholder groups and regions.

This section was designed to gather information about the types of resources stakeholders have found useful and practical in guiding their work in sustainable use of PGRFA and those that they require and consider most important to support their work in this area. Respondents were asked to provide examples of existing resources and to indicate why they have found them particularly useful and practical, as well as to list the types and topics of resources required, indicating why they are needed. conducted in which members of the Treaty's Ad Hoc Technical Committee on Sustainable Use (ACSU) representing Contracting Parties, NGOs and international organizations, as well as a member of the $\mathrm{AGDT}^{4}$ team at FAO, were invited to test and provide feedback on the content, functionality, length and style of the survey. Following the provision of feedback from the invited experts, final amendments were made and the survey was translated and transferred into the SurveyMonkey platform. The survey was launched on 27 April 2015 and available for completion until 01 June 2015. Stakeholders were invited to participate by email from the Secretary of the Treaty. The invitation

\footnotetext{
${ }^{4}$ Agriculture Department of FAO-International Treaty on Plant Genetic Resources for Food and Agriculture.
}

was initially sent to 1696 contacts across the full range of stakeholder groups and was circulated further to collegiate networks of the contacts and survey facilitators, as well as being broadcast on social media, including Facebook and Twitter. After closure of the survey, the collected data were downloaded from SurveyMonkey in MS Excel format and organized into tables in preparation for analysis. Responses from the Spanish and French surveys were translated into English and answers from the three surveys combined into one database. Univariate descriptive data analyses (frequency distributions and dispersion) of the responses to mandatory questions were carried out in MS Access and MS Excel and the results presented in bar and pie charts and/or in the narrative. Free-text responses to optional questions were ordered 
thematically and presented in tabular format (as supplementary tables). Syntheses of the key issues arising from these optional responses are presented in the narrative.

\section{Results}

Sample size and stakeholder identification

In total, there were 558 visits to the survey and $70 \%$ (392) proceeded to answer the survey questions. Out of this sample of $392,65 \%$ (254) of the respondents completed the entire survey by answering the mandatory questions across all four sections, 69\% (271) completed sections $1-3$, and $74 \%$ (289) completed sections 1 and 2 . The sample size on which the results are based therefore ranges between 254 and 289, since despite a portion of respondents not completing the entire survey, their responses to the questions of sections 2 and 3 are nonetheless informative. The 289 survey responses were received from stakeholders in 109 countries and the European Union, of which 90 are Contracting Parties to the Treaty. All FAO sub-regions were represented in the survey; however, the response rate was noticeably low from western and middle Africa, the Caribbean, and central and eastern Asia. Seventy-five percent of the respondents operate at national level in their work, $36 \%$ at regional level, and $38 \%$ at global level $\left(n=429^{5}\right)$.

Figure 2 illustrates that ten pre-defined stakeholder groups ${ }^{6}$ were represented by the survey respondents, with the largest numbers of responses from representatives of the public research, government and public genebank sectors. Many respondents belong to more than one stakeholder group. For example, 44\% (63) of respondents representing the public research sector also represent public genebanks and 37\% (52) also represent government bodies, while $32 \%$ of respondents representing farmers' associations also identify a

\footnotetext{
5 Many of the stakeholders who responded operate at more than one level.

${ }^{6}$ Pre-defined stakeholder groups: (i) public research institutes; (ii) governmental bodies; (iii) private plant breeding companies and independent plant breeders; (iv) the commercial seed and plant production industries; (v) public gene banks; (vi) farmers and seed producers; (vii) farmers' associations; (viii) seed networks; (ix) non-governmental organizations (NGOs); (x) local and indigenous communities.
}

role in public research, as do $44 \%$ of respondents representing seed networks. Individuals representing NGOs are also associated with the private/independent plant breeding and farmer/seed producer communities, commercial industries, government bodies and public genebanks, as well as farmers' associations, seed networks and local/indigenous communities. Not surprisingly, more than half of the respondents belonging to private plant breeding companies, or who are independent plant breeders, also represent the commercial seed/plant production industry. A few respondents representing local/indigenous communities indicated that they also belong to the private plant breeding/independent plant breeder group or the commercial seed/plant production industry. A small number of respondents indicated an affiliation with both the private/independent plant breeding community and the public research sector, public genebanks and government bodies, possibly indicating some misinterpretation or misreading of the categories presented in the survey. Representation of other types of stakeholder groups was reported by 47 (16\%) of the respondents (or $8 \%$ of total responses per stakeholder group-Fig. 2). These respondents are affiliated with universities/research/educational establishments, international bodies such as $\mathrm{FAO}^{7}$ UNEP, ${ }^{8}$ $\mathrm{UNESCO},{ }^{9}$ the $\mathrm{EC}^{10}$ and the $\mathrm{GEF},{ }^{11}$ and international organizations, networks or services such as the CGIAR, ECPGR, ${ }^{12}$ Red Mesoamericana de Recursos Fitogenéticos, Secretariat of the Pacific Community (SPC) and SADC ${ }^{13}$ Plant Genetic Resources Centre (SPGRC). A small number of respondents who specified an association with these types of organizations in the 'other' category also indicated that they belong to the public research and public genebank stakeholder groups.

\footnotetext{
7 Food and Agriculture Organization of the United Nations.

${ }^{8}$ United Nations Environment Programme.

${ }^{9}$ United Nations Educational, Scientific and Cultural Organization.

${ }^{10}$ European Commission.

11 Global Environment Facility.

12 European Cooperative Programme for Plant Genetic Resources.

13 South African Development Community.
} 
Fig. 2 Proportional representation of stakeholder groups based on responses $(\mathrm{n}=551)$ of the 289 respondents who fully or partially completed the survey

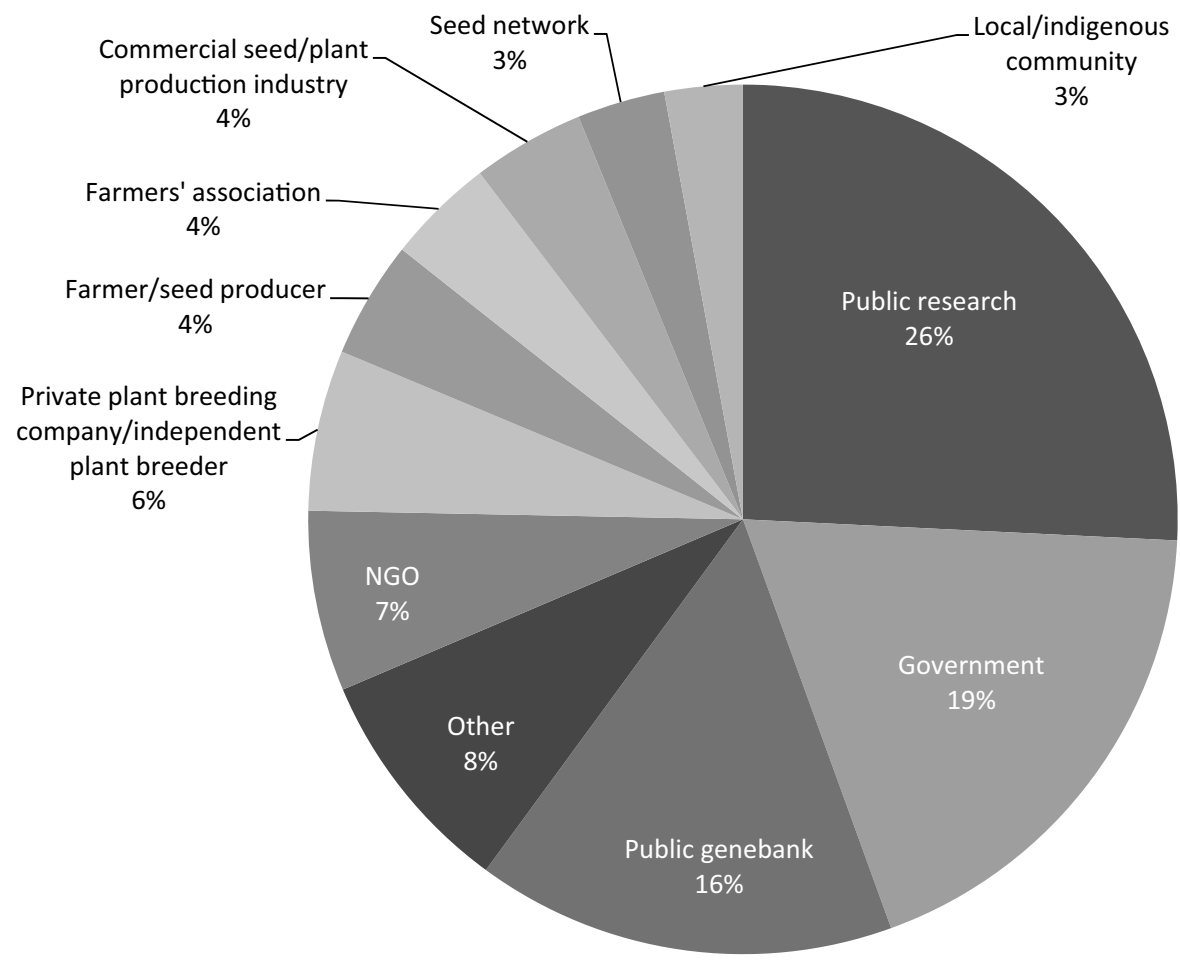

\section{Stakeholder roles in sustainable use}

The roles or interests of the respondents in the sustainable use of PGRFA were collected in 12 predefined categories reflecting aspects of the PGRFA use system (Fig. 3), with the addition of an 'other' category. A high percentage of respondents (82\%) indicated a role or interest in plant genetic diversity conservation. These respondents are primarily from public research institutes (27\%), public genebanks and government bodies (18\%), other organizations (8\%) and NGOs $(6 \%)$ - the remainder belonging to the private/independent plant breeding community, the farmer/seed producer group, commercial seed/plant production industries, seed networks, farmers' associations and local/indigenous communities $(5 \%$ or less) (Fig. 4). Of the 166 respondents who indicated a role or interest in the maintenance of a broad base of crop varieties, $93 \%$ also have a role or interest in plant genetic diversity conservation-a satisfying result confirming that plant genetic diversity conservation is not perceived as an independent activity from the maintenance of a diverse array of crop varieties. Rather, the maintenance of crop varieties is viewed as one component in the spectrum of PGR diversity conservation activities.

It is noteworthy that of the 122 respondents who play a role or are interested in participatory plant breeding (PPB) and/or participatory varietal selection (PVS), 25\% are affiliated with public research institutes, $18 \%$ with government bodies, $14 \%$ with public genebanks, and $9 \%$ with NGOs (Fig. 5). Six percent belong to the farmer/ seed producer stakeholder group and other organizations, 5\% to farmers' associations and the private/ independent plant breeding group, and $4 \%$ to local/ indigenous communities, seed networks and the commercial seed/plant production industries. This may reflect a need for greater efforts to bring together the public and private sectors in participatory approaches to plant breeding through the promotion of public-private partnerships (PPP). Other specific roles or interests in sustainable use of PGRFA reported by 32 respondents are wide-ranging and can be broadly classified into six groups: (a) plant breeding and crop improvement; (b) the seed system, diversification and marketing; (c) research and data access; (d) policy and economics; (e) public awareness, education and capacity building; and (f) international and cross-sector collaboration (Table S1). 


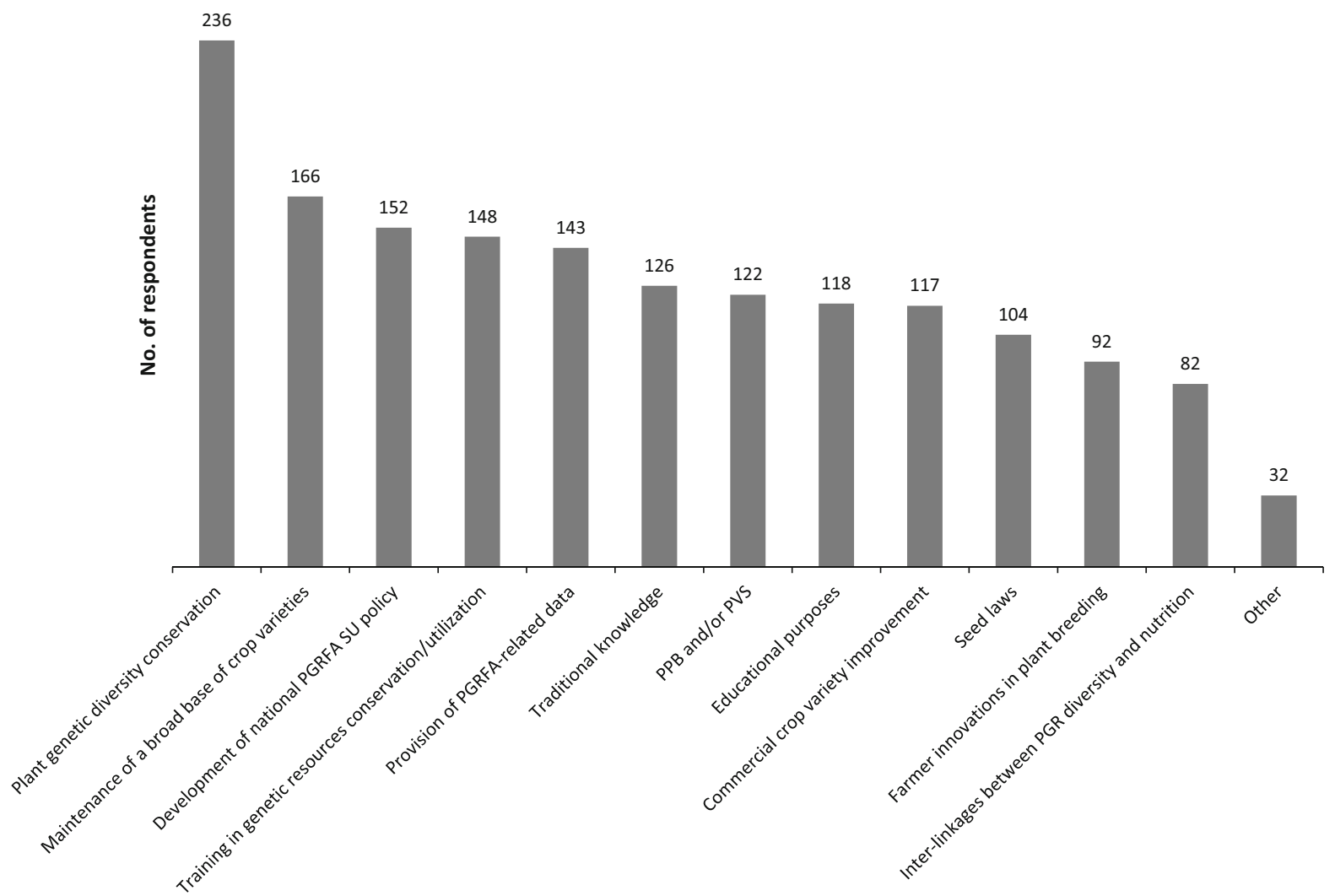

Fig. 3 The roles or interests of the 289 respondents who fully or partially completed the survey

Strengths and weaknesses of the PGRFA use system

To identify where the perceived bottlenecks are in the PGRFA use system, survey participants were asked to indicate their level of agreement with ten positive statements related to aspects of the system (Fig. 6) and to substantiate their answers. A significant percentage of respondents (in the range of $17-36 \%$ across the statements) stated that they neither agreed nor disagreed with the statements, or that they were either not sure or did not know. There is clearly a concern regarding policies to promote farmer innovation in plant breeding and marketing opportunities for landraces/farmers' crop varieties, with significantly more respondents stating that they disagreed (or strongly disagreed) with these two statements (43 and $42 \%$ respectively) than those who agreed (or strongly agreed) (25 and
$26 \%$ respectively). In the case of policies to promote farmer innovation in plant breeding, most respondents who disagreed (or strongly disagreed) simply stated that there are no policies in place at all, while other respondents provided more detailed views (Table S2). The explanations of respondents who disagreed (or strongly disagreed) with the statement that there are adequate marketing opportunities for landraces/farmers' crop varieties can be summarized as: (a) informal markets are available (e.g., weekly marketing fairs) but existing policies discourage such markets (e.g., through prohibitive legislation regarding variety registration and seed certification); (b) there is potential but efforts are minimal or ad hoc and require further strengthening and financial support; (c) commercial markets tend to favour uniformity over diversity, discouraging rather than adding value to local crop diversityopportunities for formal marketing of farmer 
Fig. 4 Proportional representation of stakeholder groups based on responses $(n=469)$ of the 236 survey respondents who indicated a role or interest in plant genetic diversity conservation

Fig. 5 Proportional representation of stakeholder groups based on responses $(n=280)$ of the 122 survey respondents who indicated a role or interest in PPB and/or PVS
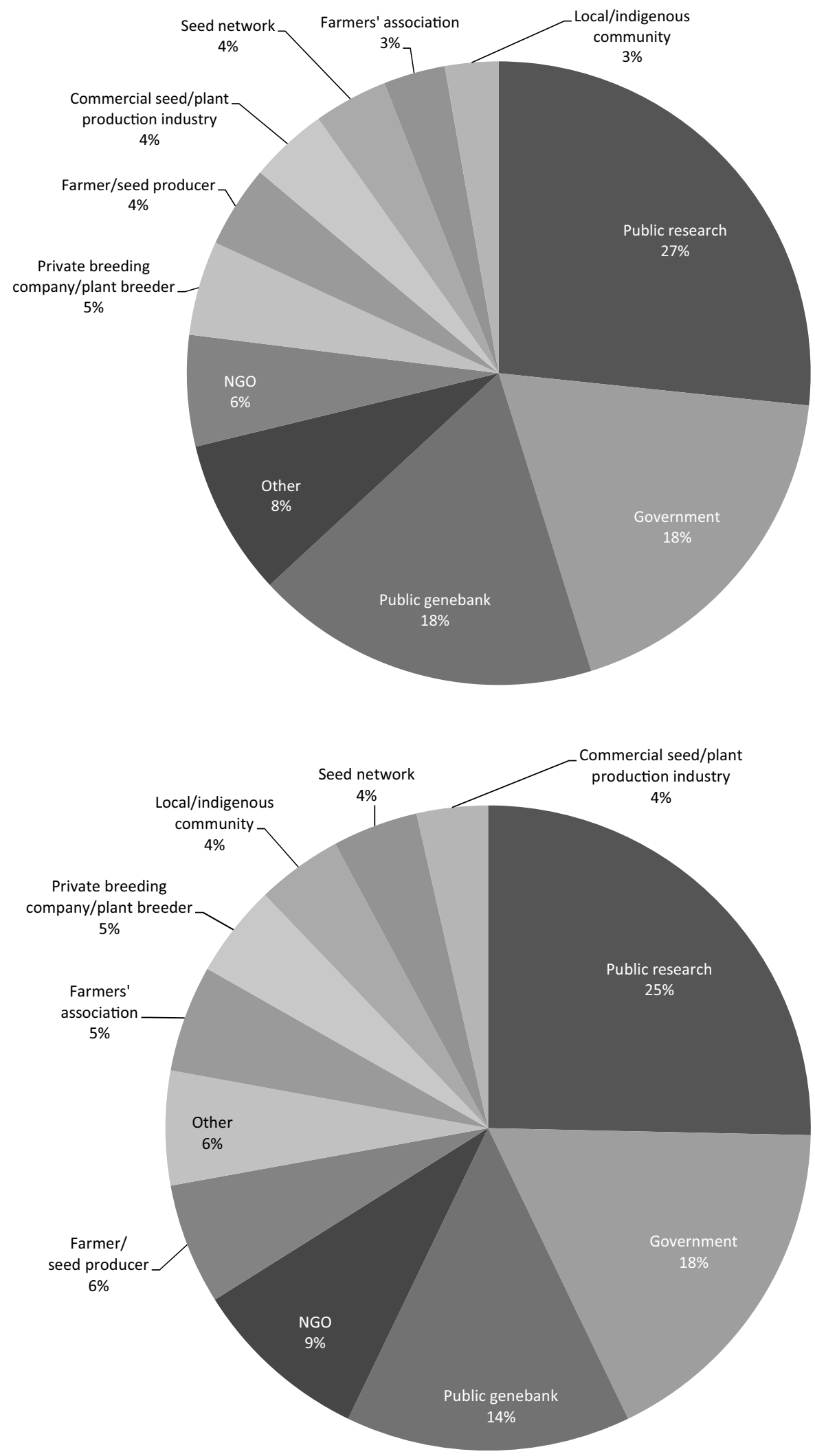


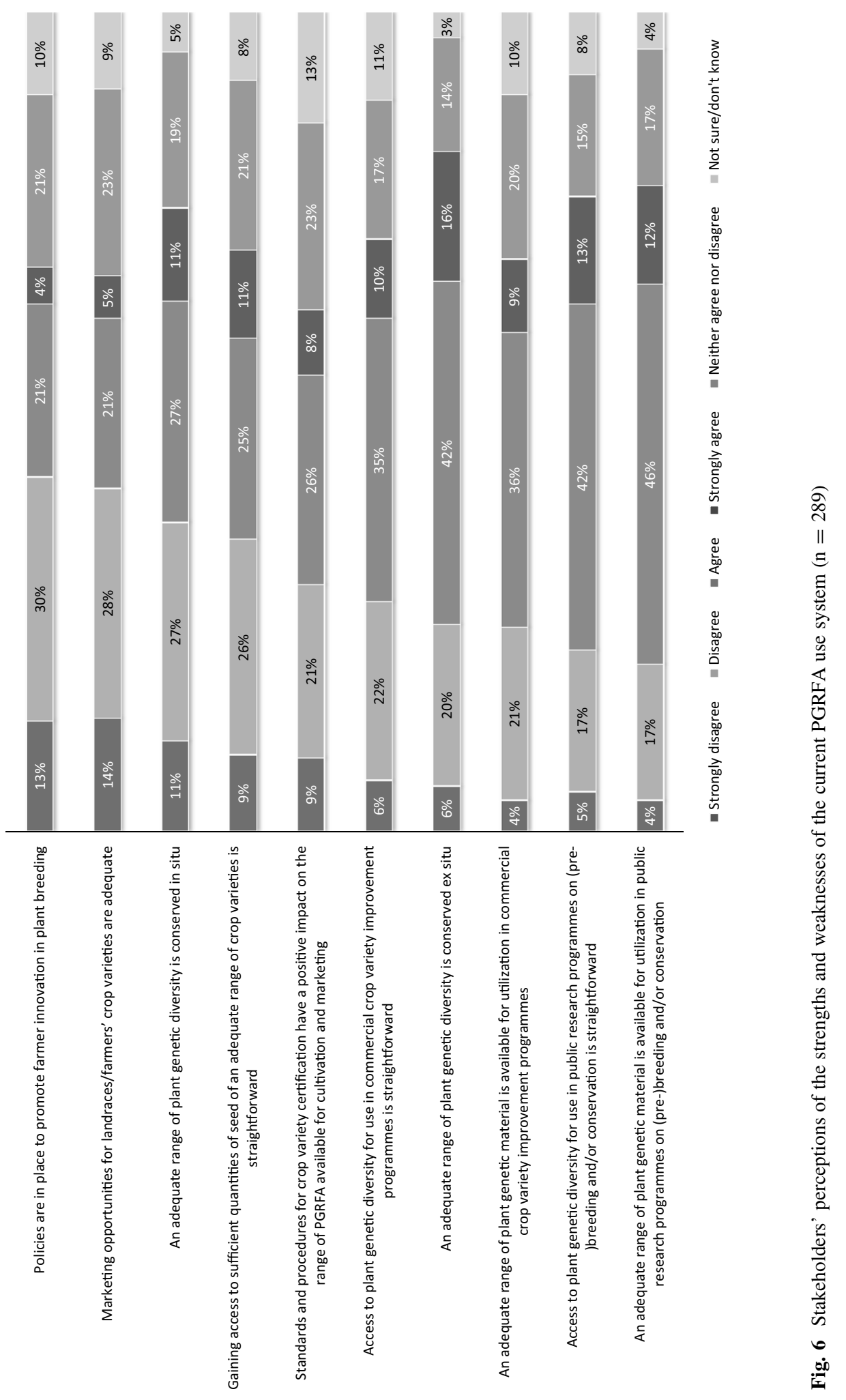


varieties are inadequate; (d) policy to support marketing of landraces/farmers' varieties exists but it is not well known or properly implemented; and (e) there is insufficient awareness of the advantages and benefits of diverse landraces/farmers' varieties.

Interestingly, the proportions of respondents who disagree/strongly disagree and who agree/strongly agree that an adequate range of plant genetic diversity is conserved in situ are equal. The explanations given by respondents who disagreed (or strongly disagreed) can be summarized as:

- There is limited financial, institutional and policy support for in situ conservation;

- In situ conservation is difficult to promote and manage;

- There are restrictions on accessing material conserved in situ;

- Infrastructure and trained human resources capacities are lacking;

- There is no widely applied approach for on-farm conservation;

- Conservation and dynamic management on-farm are not recognized;

- Local varieties are being replaced with highly bred commercial high yielding varieties;

- There is no targeted or active conservation of crop wild relatives in existing protected areas;

- PGRFA in situ are threatened by human activities.

The respondents who indicated that they believe there to be adequate plant genetic diversity conserved in situ fall into three main groups: (a) those who consider the existing protected area system adequate to conserve PGRFA in situ; (b) those who consider that on-farm conservation is an inherent activity being managed by farmers; and (c) those who erroneously confuse ex situ conservation in field genebanks with in situ conservation. A fourth group appeared to mistakenly refer to ex situ conservation in their comments. The response to the adequacy of plant genetic diversity conserved in situ indicates that there is a need to raise awareness of what constitutes in situ conservation, its fundamental importance for effective preservation of genetic diversity, and the current lack of an infrastructure for systematic PGRFA conservation in situ.

For the other seven statements regarding the strengths and weaknesses of the current PGRFA use system, although there is greater agreement than disagreement, a significant proportion of respondents disagree with each (Fig. 6). Therefore, it is vital that these issues are addressed to strengthen the system and support the sustainable use of PGRFA. For example, gaining access to sufficient quantities of seed of an adequate range of crop varieties is perceived as problematic because:

- Smallholder farmers are restricted by the cost of seed and inadequate distribution channels;

- A lack of resources and skills are hampering seed production;

- Quantities of seed in genebanks are limited and systems for multiplication are lacking;

- Many crops are unattractive to seed companies;

- Minor crops with less commercial potential have been heavily neglected in breeding and therefore the available varieties do not meet the need of farmers;

- There is no integrated system that facilitates access to farmers' seeds while recognizing and protecting Farmers' Rights.

Many respondents commented that standards and procedures for crop variety certification: (a) are complicated, bureaucratic and too costly for many farmers; (b) are not appropriate for landraces/farmers' varieties because the material is often not sufficiently uniform and stable; (c) have a negative impact on the marketing of landraces/farmers' varieties; (d) have contributed to the genetic erosion of on-farm plant genetic diversity; (e) restrict the range of PGR available for breeding new crop varieties; and (f) hinder the functioning of local seed systems.

Access to plant genetic diversity for use in public research programmes is also a critical bottleneck in the system due to:

- Problems with accessing material held in national genebanks (e.g., material requests are not honoured and there is confusion regarding the operation of the Multilateral System-MLS) - thus, public research and breeding programmes must rely on self-collected materials or those sourced from international genebanks or commercial sources;

- Complicated, time-consuming and costly procedures, particularly within the public genebank system; 
- Insufficient policies and guidelines;

- Compliance with national access and benefitsharing (ABS) regulations;

- Inadequate access to passport, characterization and evaluation data on the plant material available;

- Conflicts between national and international policies (e.g., material transfer agreements-MTAs, IPRs and Farmers' Rights);

- Fragmentation of policies and conservation facilities.

Similar reasons are given for difficulties in accessing plant genetic material for use in commercial crop improvement programmes, although with the added issue that some companies are cautious of potential future claims on royalties due to IPRs and ABS regulations.

Other issues regarding the weaknesses of the current PGRFA use system highlighted by respondents were:

- Genebank curators and plant breeders seldom collaborate in base broadening or population development;

- Human and institutional capacities for conserving PGRFA and using them in pre-breeding and plant breeding are limited due to lack of skills and resources available;

- Many accessions held in genebanks may be unviable due to prevailing poor funding and weak infrastructure;

- No black box arrangements are in place for the conservation of farmers' varieties-the link between farmers and national genebanks needs to be strengthened and Farmers' Rights guaranteed;

- Media promotion of the work of NGOs and powerful oligopolistic retailing is having a negative impact on the implementation of serious PGR policy and activities;

- Weak compliance by Contracting Parties to the provisions of the Treaty, particularly regarding the MLS;

- Clashes between the provisions of the Treaty and the International Union for the Protection of New Varieties of Plants (UPOV);

- Lack of public awareness about the importance of PGRFA;

- Fragmented approaches in research and policymaking.

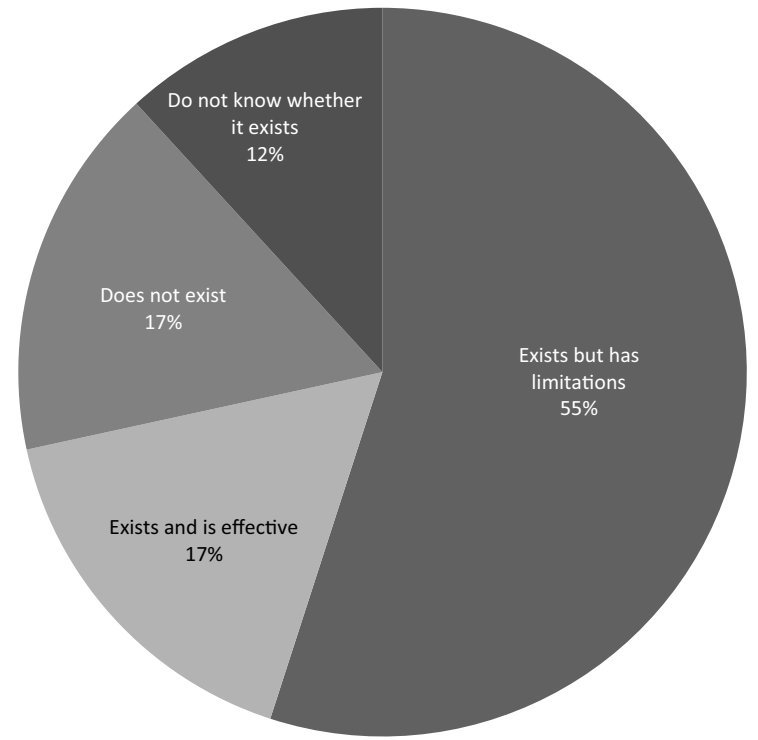

Fig. 7 Stakeholders' responses regarding national policy in support of sustainable use of PGRFA $(n=271)$

Constraints and needs regarding

the implementation of sustainable use strategies

\section{National policy in support of sustainable use}

More than half of the survey respondents indicated that national policy in support of the sustainable use of PGRFA $^{14}$ in the country(ies) in which they (or the stakeholder group(s) they represent) work exists, but that it does not cover all elements of sustainable use of PGRFA and/or there are problems with its implementation (Fig. 7). Seventeen percent of respondents consider that national policy in support of the sustainable use of PGRFA exists and is both comprehensive and effective, but the same percentage believe that it does not exist at all. The remaining 12\% indicated that they did not know about national policy related to the sustainable use of PGRFA. There was strong concurrence among the $149(55 \%)$ respondents

\footnotetext{
$\overline{14}$ As defined in the survey, "for example, policy to support: maintenance of diverse farming systems; PPB/PVS; farmer innovation/Farmers' Rights; maintenance/marketing of landraces/farmers' varieties; use of under-utilized species; conservation of plant genetic diversity in situ and ex situ; use of a wide diversity of species and varieties on-farm; seed (exchange) networks; recognition of the value of traditional knowledge; access to plant genetic diversity for use in breeding programmes; access to information on plant genetic diversity".
} 


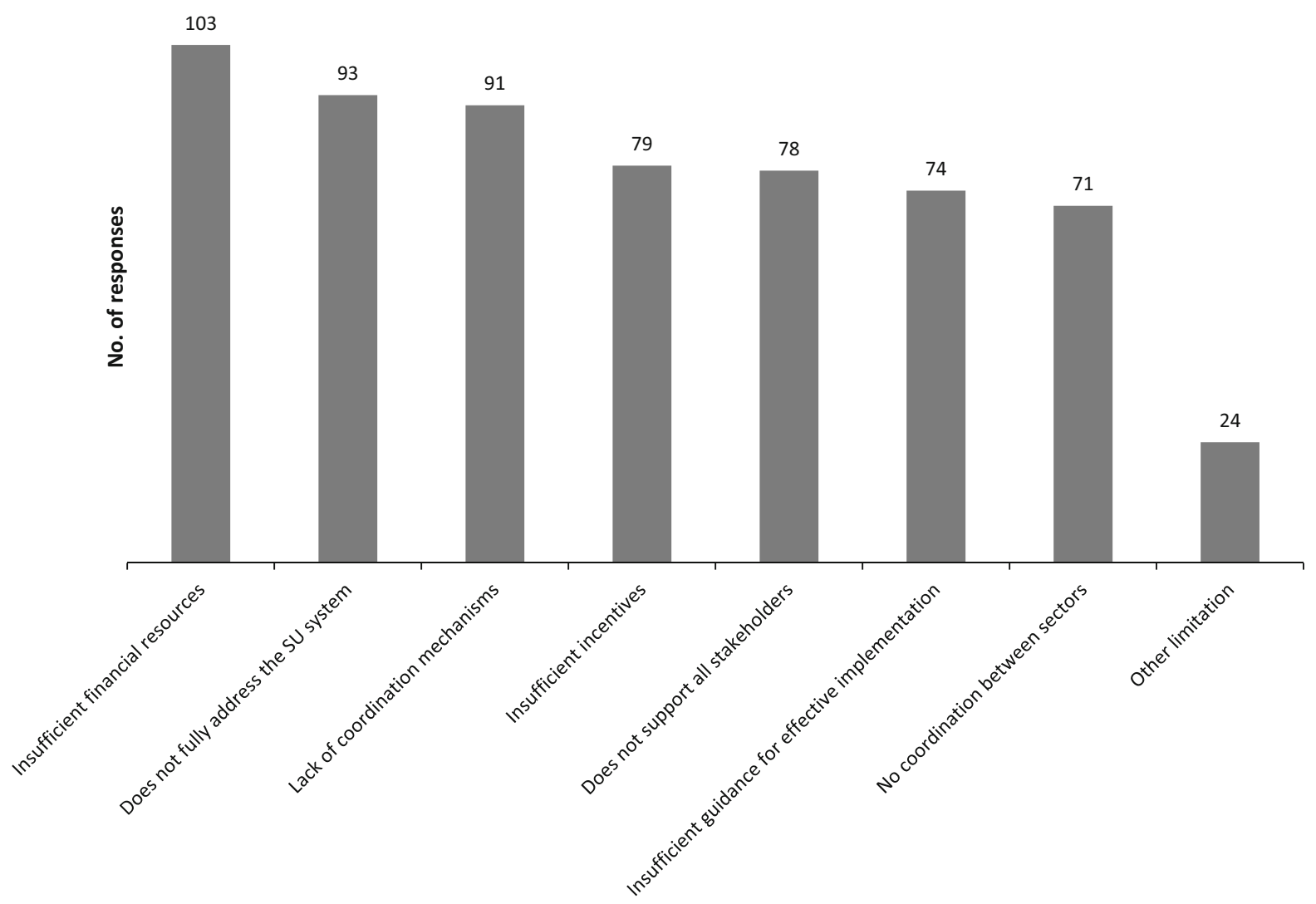

Fig. 8 Limitations of national policy in support of sustainable use of PGRFA reported by 149 survey respondents $(\mathrm{n}=613$ )

who indicated that national policy in support of sustainable use exists but has limitations, with seven pre-defined categories of limitations (Fig. 8). A large proportion of these respondents substantiated their answers with specific information on the types of policies missing, the stakeholder groups that are not supported, the types of incentives and guidance needed, the areas of the PGRFA system in which financial resources are needed, and how coordination between public administrations and/or between the public and industry sectors could be improved (Table S3). The need for policies to recognize and support informal seed systems, smallholder farmers maintaining local diversity, and regulations governing the certification and marketing of landraces/farmers' varieties was frequently mentioned, as were those to recognize and support Farmers' Rights, farmer led initiatives/farmer innovation and participatory approaches to crop improvement. Policies to address ABS issues and to support in situ conservation of PGRFA (both wild and cultivated) are also critically needed. Overwhelmingly, respondents highlighted farmers as the stakeholders who are not currently adequately supported by national policy in support of sustainable use of PGRFA.

While the incentives needed to implement national policy include financial support (e.g., for the development of crops suitable for national production, special programmes to provide incentives to farmers, or to support participatory or diversity-oriented approaches), several non-monetary incentives were also highlighted, including the formal recognition of the role of farmers and local communities in the conservation and sustainable use of PGRFA, provision of training and technical support (e.g., in conservation and plant breeding techniques), and improved public awareness on the status and importance of PGRFA for economic and social development. Respondents highlighted the need for guidance in a diverse range of topics to aid the implementation of policy on sustainable use of PGRFA, including guidance in policy development to implement the Treaty itself. The need for guidance in developing collaboration between the conservation and breeding sectors was also strongly emphasized. 
In terms of financial resources required, the most frequently mentioned need was for long-term support for national gene banks, as well as funding for in situ conservation, the provision of support to maintainers of landraces/farmers' varieties and for local seed systems, and for strengthening markets for local diverse products. A number of respondents consider that financial support is required for all facets of the PGRFA conservation and use system. Several proposals for improving coordination between public administrations and/or between the public and industry sectors were put forward, the most frequent being the establishment of national committees involving representatives of all stakeholder groups, and encouraging PPP for plant breeding. Other limitations to the implementation of national policy in support of sustainable use reported were:

- The need to increase awareness of decisionmakers of the value of PGRFA for food security;

- The lack of clear policy in many countries on ABS, making it difficult to find out what rules apply and to negotiate ABS obligations;

- Insufficient support for breeding activities by small seed companies;

- The topic of conservation and sustainable use of PGRFA is not even on the agenda at national decision-making level;

- The improvement of crops not listed in Annex I of the Treaty is hindered by the Nagoya Protocol;

- There are no effective public policies to support research, training and incentives to counterbalance the dominance of the private sector and which are conducive to sustainable use of PGRFA;

- Existing national policy is for biodiversity in general and does not specifically address PGRFA;

- Existing national policy focuses only on ex situ conservation and does not recognize conservation and dynamic management on-farm or protection of Farmers' Rights;

- A paradigm shift is needed to place farmers at the centre of the sustainable management of PGRFA within the context of Article 6 of the Treaty.

\section{Capacity building needs}

Results show an overwhelming need for both human and institutional capacity building to help stakeholders effectively implement the sustainable use provisions of

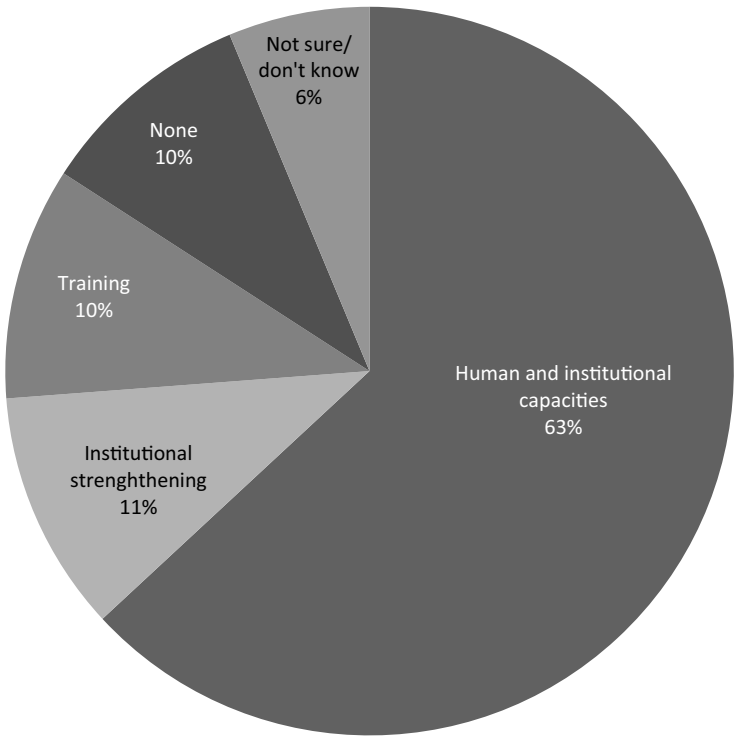

Fig. 9 Stakeholders' capacity building needs for enacting the sustainable use provisions of the Treaty $(n=271)$

the Treaty (Fig. 9) and a critical need for capacity building in all areas of the PGRFA sustainable use spectrum (Fig. 10). The highest numbers of respondents indicated a requirement for capacity building in sustainable use policy development and/or implementation (65\%), novel characterization techniques to speed up the identification of target trait sources (e.g., using phenomics, genomics and transcriptomics, and/or predictive characterization techniques) (63\%), and providing/improving market opportunities for landraces/farmers' varieties (61\%). Between 42 and 56\% of respondents identified a need for capacity building in the other nine pre-defined categories reflecting areas of the PGRFA use system, with capacity building in plant (pre-)breeding technology being identified as important by $42 \%$ of respondents, and establishing and managing PPP for plant breeding by $56 \%$. Other types of capacity building needs were identified by $11 \%$ of respondents and can be summarized as: (a) support to enable a review of regulatory and policy frameworks to improve the implementation of Farmers' Rights (for farmers, researchers and policy-makers); (b) training in the implementation of Farmers' Rights; (c) awarenessraising about the importance of PGRFA conservation and sustainable use amongst national policy-makers, farmers and the general public; (d) defining the roles of the informal and formal breeding and seed sectors in PGRFA sustainable use; (e) cross-sector collaboration in in situ PGRFA conservation planning; 


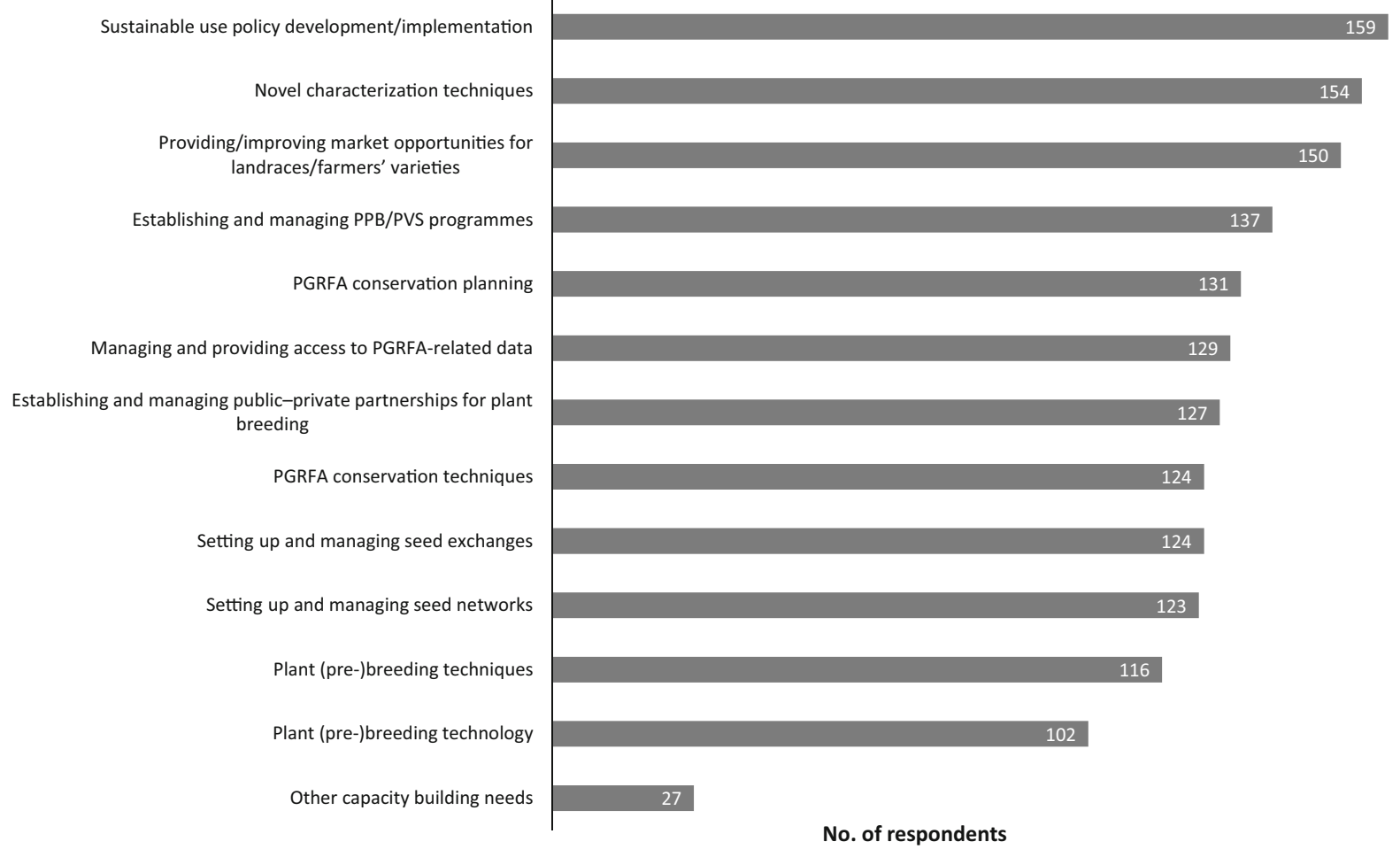

Fig. 10 Capacity building needs reported by 245 survey respondents

(f) conservation and sustainable use of neglected and underutilized species; $(\mathrm{g})$ understanding the implications of IPR on the use of PGRFA; (h) awarenessraising about the importance of PGRFA conservation and sustainable use within the academic community; and (i) ecological and social modelling.

An analysis of capacity building needs of individual stakeholder groups reveals that on the whole, there is fairly uniform agreement across groups regarding the relative importance of the pre-defined categories reflecting areas of the PGRFA use system (Fig. S1). However, it is noteworthy that no representatives of farmers' associations indicated a need for capacity building in PPP for plant breeding, and that setting up and managing seed networks is of far greater interest to representatives of government agencies and public research institutes than it is to the commercial seed/plant production industry, farmers/seed producers, farmers' associations and local/indigenous communities. This indicates a need for focussed support in these areas and for the development of strategies and mechanisms for greater cross-sector collaboration. It may also be important to address differing capacity building needs driven by the geo-diverse socioeconomic and political landscape. Table 2 presents a summary of the indications resulting from an analysis of capacity building needs across and within continental (macro) regions. ${ }^{15,16}$ The results of the analysis are presented in Figs. S2a-e.

Constraints regarding access to PGRFA material or associated information

A significant proportion of stakeholders face difficulties in accessing PGRFA material (germplasm) or

\footnotetext{
15 Based on macro geographical (continental) regions and geographical sub-regions as defined by the United Nations Statistics Division-http://unstats.un.org/unsd/methods/m49/ m49regin.htm.

${ }^{16}$ Results are based on a large variation in the number of respondents per macro region and sub-region-the highest number at macro regional level was 124 respondents representing Europe and the lowest 22 respondents representing Oceania, while at sub-regional level the highest number was 45 respondents representing western Europe and the lowest, one respondent representing the Caribbean and one Central Asia.
} 
associated information ${ }^{17}$ required for sustainable use (Fig. 11). Accessing information on plant genetic material containing specific traits is of particular concern, with $54 \%$ of respondents $(n=271)$ identifying this as a constraint impinging on effective sustainable use of PGRFA. Thirty-nine percent of respondents face difficulties in obtaining plant genetic material for crop improvement, $38 \%$ in obtaining information on plant genetic material for crop improvement and on plant genetic diversity for conservation planning, $36 \%$ in obtaining information on conserved plant genetic diversity, and $31 \%$ on potential collaborators for crop improvement programmes. While a significant proportion of respondents stated that they do not face difficulties in accessing PGRFA material or related information, this by no means negates the need to address these issues as a priority through the provision of resources to mitigate these bottlenecks which are clearly impacting a substantial number of stakeholders in the PGRFA use system. One hundred and twenty-one respondents elaborated on their responses regarding these access issues (Table S4). The main constraints can be summarized as: (a) insufficient characterization and evaluation is undertaken across a broad spectrum of crop gene pools; (b) for material that has been characterized and/or evaluated, access to the resulting data is problematic due to inadequate data management in national gene banks; (c) germplasm collections are rarely established on the basis of targeted genetic diversity; (d) much information on PGRFA material is not available in the public domain; (e) information on material containing specific traits is difficult to obtain; (f) determining and following the legal steps required to obtain germplasm is complex and time-consuming; (g) plant genetic material requested is sometimes not forthcoming; (h) obtaining information on potential collaborators for crop improvement programmes is difficult; and (i) access to germplasm and information is hampered by poor communication technology, lack of human resources,

\footnotetext{
17 'Information' in this context was not defined in the survey to allow free interpretation of the questions by the respondents. However, such information may include: taxonomic data (including gene pool concepts); in situ population occurrence data; ex situ collections data (e.g., taxa available; passport data; characterization and evaluation data; trait data; and quantity of germplasm available).
}

language barriers and restricted access to scientific literature.

Types of resources required to support stakeholders in sustainable use of PGRFA

Figure 12 indicates that a wide range of types of resources are important to support stakeholders' work in sustainable use of PGRFA, although perhaps not surprisingly, websites, web portals and online databases are the highest rated categories. Other types of resources important for stakeholders are notifications about conferences, field demonstration events, courses and training workshops, as well as access to knowledge networks and social media. Respondents provided many examples of online resources which they have found particularly useful and practical. These include the websites of international organizations such as FAO, the CGIAR, and the Crop Trust ${ }^{18}$; the Treaty and the CBD; and knowledge networks such as PAR, ${ }^{19}$ GFAR,${ }^{20}$ WIEWS, ${ }^{21}$ ECPGR and EUCARPIA. $^{22}$ Online databases of note are GBIF, ${ }^{23}$ Genesys, ${ }^{24}$ The Harlan and de Wet Crop Wild Relative Inventory, ${ }^{25}$ EURISCO ${ }^{26}$ GRIN Taxonomy for Plants, and Mansfeld's World Database of Agricultural and Horticultural Crops. ${ }^{27}$ Respondents also highlighted the importance of individual gene bank and company websites, and online genome databases. Online resources are considered useful and practical in supporting stakeholders' activities due to their ease of

\footnotetext{
18 The Crop Trust (formerly the Global Crop Diversity Trust) www.croptrust.org.

${ }^{19}$ Platform for Agrobiodiversty Researchagrobiodiversityplatform.org.

${ }^{20}$ The Global Forum on Agricultural Research-www.egfar. org.

21 World Information and Early Warning System on PGRFAwww.fao.org/wiews-archive/wiews.jsp.

${ }^{22}$ European Association for Research on Plant Breedingwww.eucarpia.org.

${ }^{23}$ Global Biodiversity Information Facility-www.gbif.org.

${ }^{24}$ Genesys, Gateway to Genetic Resources-www.genesyspgr.org/welcome.

${ }^{25}$ Crop Wild Relatives and Climate Change-www. cwrdiversity.org/checklist.

${ }^{26}$ EURISCO, Finding seeds for the future-eurisco.ipkgatersleben.de/.

27 Mansfeld's World Database of Agricultural and Horticultural Crops-mansfeld.ipk-gatersleben.de.
} 


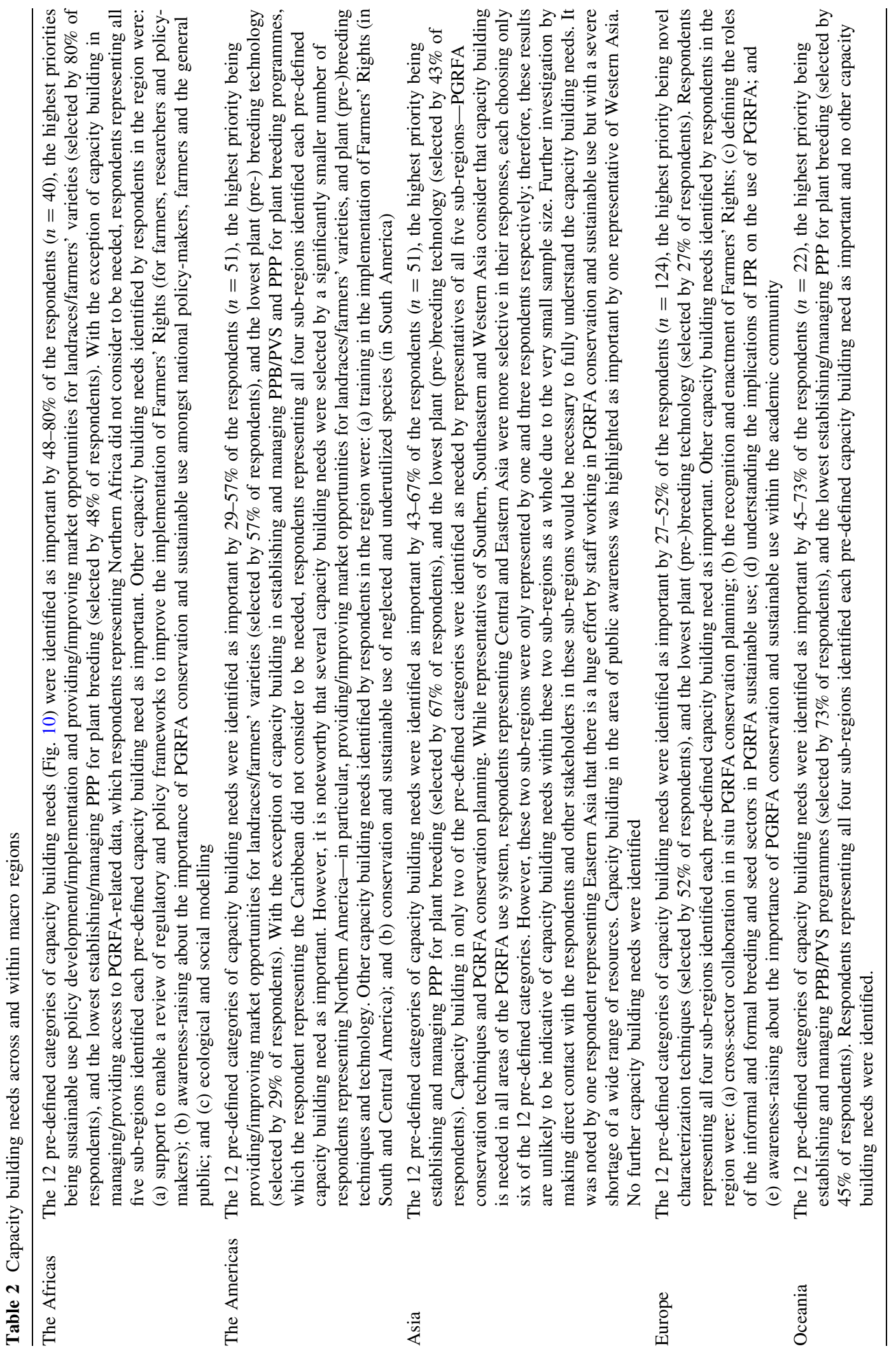




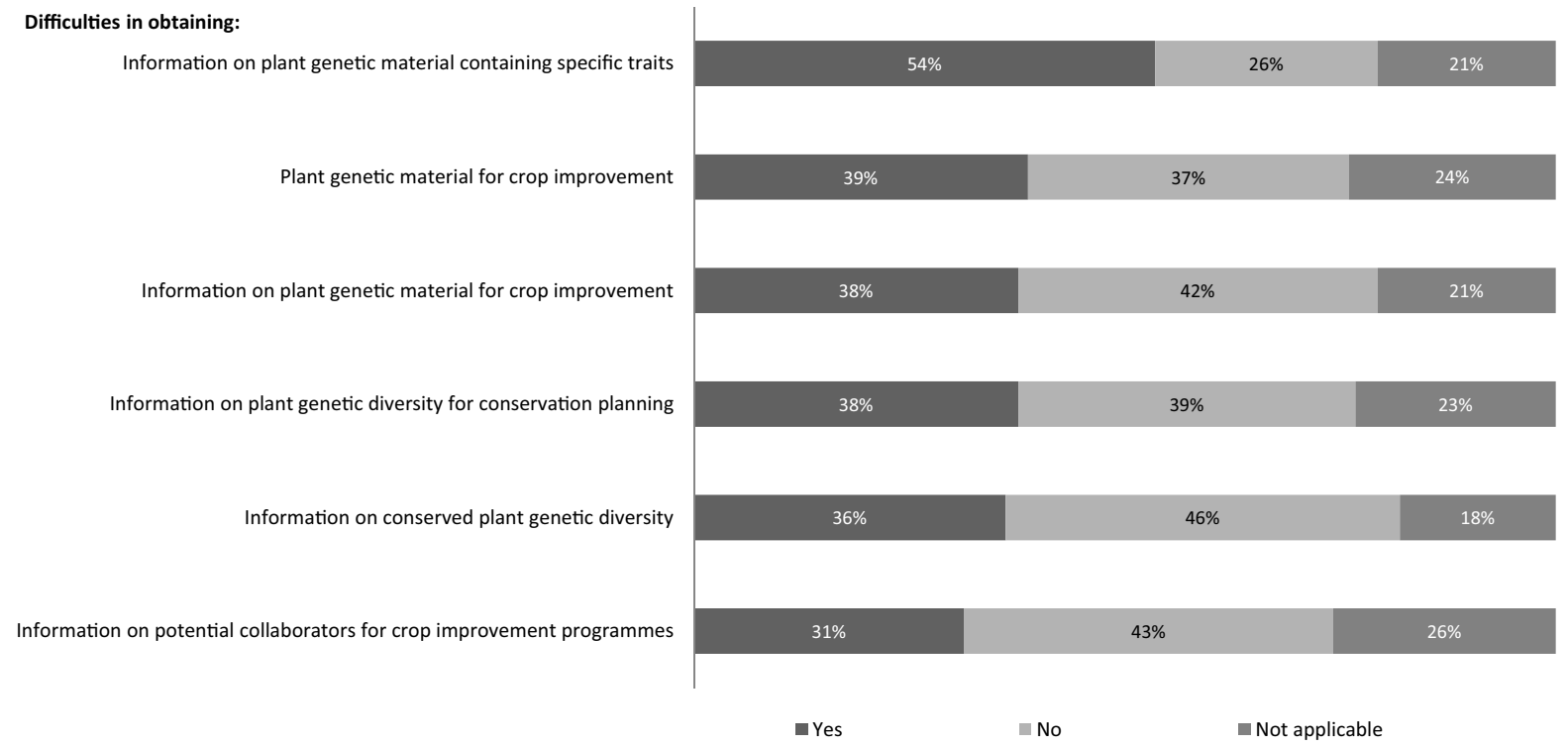

Fig. 11 Constraints regarding access to PGRFA material (germplasm) or related information required for sustainable use $(\mathrm{n}=271)$

access, free availability, reliability and speed, the wealth of information they contain or provide access to, and opportunities for networking. In addition to online resources, respondents provided a broad range of examples of other types of resources and indicated why they found them useful and practical (Table 3). Figure 13 illustrates the relative importance of 11 specific tools and resources which could support stakeholders. All are considered to be vital by a proportion of the respondents (14-39\%), while $37-61 \%$ of respondents consider them to be important. There was a degree of uncertainty about the value of the tools and resources-particularly with regard to web-based policy decision tools and an online discussion platform in which to share news, information and knowledge on sustainable use of PGRFA - and a proportion of respondents believe the tools and resources not to be important. However, these opinions are far outweighed by respondents considering them all to be either vital or important. Respondents also provided specific examples of resources they require to support their work in sustainable use of PGRFA (Table S5).

\section{Discussion}

The results of the survey have allowed a clearer understanding of the bottlenecks in the PGRFA use system and a deeper comprehension of stakeholders' specific constraints and needs regarding the implementation of actions to promote the sustainable use of PGRFA. There is clearly an urgent need to address national policy in support of sustainable use since 17\% of respondents consider that national policy in this area does not exist at all and only $17 \%$ indicated that the required policy exists and that it is both comprehensive and effective. While FAO (2010) highlighted that many countries do not have strategies and plans in place for PGRFA conservation and use, the results of the current analysis not only show the scale of the problem but also emphasize that it is not enough to simply have national policy in place. More than half of the respondents believe that policy exists but that it does not cover all elements of sustainable use of PGRFA and/or there are problems with its implementation, a problem highlighted by Vorley et al. (2012) in a study of the role of national policies in inclusive and sustainable agricultural development. Further, the results of the current survey provide an insight into the types of missing policies, of which respondents reported that there are many-particularly those for the recognition and support of informal seed systems, smallholder farmers maintaining local diversity, and regulations governing the certification and marketing of landraces/farmers' varieties, as well as to recognize and support Farmers' Rights, farmer led initiatives/farmer innovation, and participatory approaches 


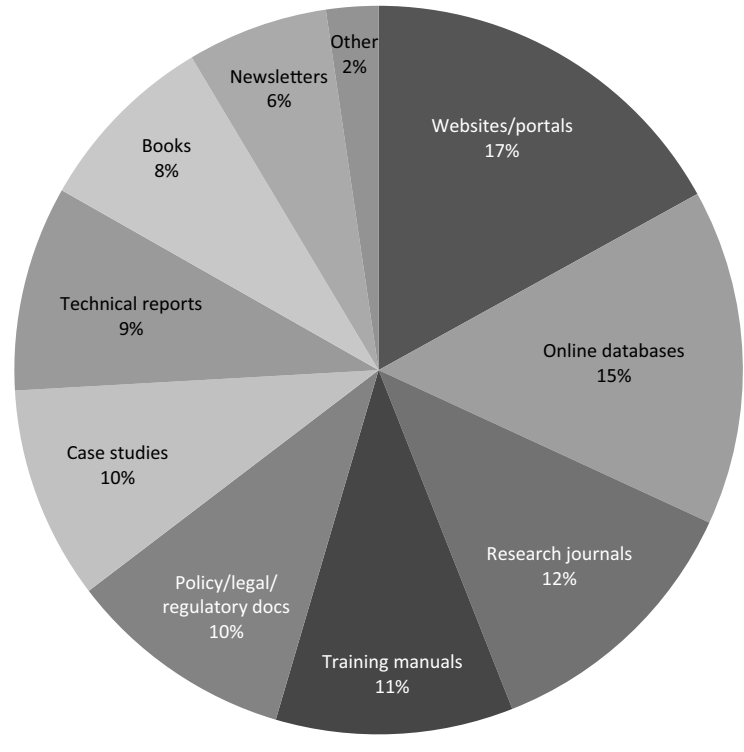

Fig. 12 Types of resources that respondents have found particularly useful and practical in guiding their work on sustainable use of PGRFA $(\mathrm{n}=254)$

to crop improvement. In addition, the survey revealed that some stakeholder groups are not supported by existing policies-in particular, farmers. Respondents also highlighted the need for more financial resources, non-financial incentives such as the formal recognition of the role of farmers and local communities, and guidance in many areas, including how to develop collaboration between the conservation and breeding sectors. The need for improved coordination between public administrations and/or between the public and industry sectors was also strongly emphasized-for example by establishing national stakeholder committees and encouraging public-private partnerships for plant breeding.

Ineffective enabling of national policy to support traditional farming systems was cited by Grum et al. (2008) as a reason why many countries in Sub-Saharan Africa are unable to meet their obligations under the CBD and Global Plan of Action on Conservation and Sustainable Use of PGRFA (GPA) ${ }^{28}$ with regard to in situ (on-farm) conservation, and as Vorley et al. (2012 p. 68) noted, "despite much diversity in contexts and policies, prevailing policy frameworks are skewed against small-scale farmers, and against

\footnotetext{
${ }^{28}$ Now the Second Global Plan of Action for PGRFA-www. fao.org/agriculture/crops/thematic-sitemap/theme/seeds-pgr/gpa/ en/.
}

women in smallholder agriculture". While FAO (2010) reported progress in the development and enactment of policies to recognize Farmers' Rights or the integration of Farmers' Rights in existing policies in some countries, it is clear from the results of the current survey that much more needs to be done in this area. Sperling and McGuire (2010) noted the lack of attention paid to informal seed markets by governments (and researchers), despite their importance for seed and food security. Their research has shown that farmers obtain as much as $90 \%$ of their seed either by self-saving or through informal channels-including local markets, neighbours, friends and relatives (Sperling and McGuire 2016). Louwaars et al. (2013) emphasized the need for seed policies to be adapted to recognize the fundamental importance of informal systems and developed the Integrated Seed Sector Development (ISSD) model. This approach has been adopted in Ethiopia where the importance of informal and intermediary seed systems in facilitating access to crops and varieties preferred by farmers at the local level has been recognized by policy-makers through advocacy, and this has resulted in the development and implementation of specific policies to support these systems (ISSD Ethiopia 2016). Vorley et al. (2012) also provide examples of policy innovations that have supported small-scale farmers by influencing the operation and outcomes of agricultural investments and markets. Therefore, while the constraints related to national policy in support of sustainable use of PGRFA are manifold and widespread, there are examples available to show how they can be successfully overcome.

Access to plant genetic material (germplasm) and associated information (e.g., information on material containing specific traits, conserved plant genetic diversity and potential collaborators for crop improvement programmes) is also a fundamental issue that urgently needs to be addressed in order that countries can move ahead with the development of coordinated and comprehensive sustainable use strategies. The main constraints revealed by this survey relate to: (a) a lack of characterization and evaluation of material in a wide range of crop gene pools; (b) inadequate data management in national gene banks; (c) non-targeted germplasm collection strategies; (d) lack of information on PGRFA material and traits in the public domain; (e) the complexities of following the legal steps required to obtain germplasm; and (f) insufficient 
Table 3 Characteristics of the types of resources which are useful and practical in supporting stakeholders' work on sustainable use of PGRFA

\begin{tabular}{|c|c|}
\hline $\begin{array}{l}\text { Online resources (websites, web portals } \\
\text { and databases) }\end{array}$ & $\begin{array}{l}\text { - Easily accessible } \\
\text { - Freely available } \\
\text { - Reliable and fast } \\
\text { - Contain or provide access to a wealth of information } \\
\text { - Provide networking opportunities }\end{array}$ \\
\hline Policy, legal and regulatory documents & $\begin{array}{l}\text { - Indicate high priorities for national policy- and decision-makers } \\
\text { - Set the framework for national action } \\
\text { - Provide examples to inform the development of national policy } \\
\text { - Aid policy compliance } \\
\text { - Identify which policies can accommodate issues of PGRFA } \\
\text { - Allow different actors to learn and understand the range of challenges related to the } \\
\text { use of PGRFA } \\
\text { - Provide visions for the future }\end{array}$ \\
\hline Training manuals & $\begin{array}{l}\text { - Users can learn alone and in their own time } \\
\text { - Practical and easy to understand } \\
\text { - Provide focussed practical and theoretical information } \\
\text { - Easily distributed and shared with relevant stakeholders } \\
\text { - Can be adapted and used by trainers } \\
\text { - Provide capacity building for junior staff and technicians }\end{array}$ \\
\hline Technical reports & $\begin{array}{l}\text { - Impart the latest information } \\
\text { - Offer crop-specific information } \\
\text { - Train the trainer } \\
\text { - Provide easy and free access for teachers and students } \\
\text { - Present realistic results of situations on the ground in similar areas } \\
\text { - Helpful as guidelines for ITPGRFA associated activities }\end{array}$ \\
\hline Case studies & $\begin{array}{l}\text { - Impart information on specific issues/topics } \\
\text { - Provide examples of lessons learned } \\
\text { - Highlight strengths and weaknesses of actions already taken and help to avoid risks } \\
\text { - Offer guidance on how/where to start collating information } \\
\text { - Can be used in teaching and training }\end{array}$ \\
\hline Newsletters & $\begin{array}{l}\text { - Provide publicity and visibility } \\
\text { - Impart the latest information } \\
\text { - Easily distributed }\end{array}$ \\
\hline Research journals & $\begin{array}{l}\text { - Reliable (as peer-reviewed) } \\
\text { - Serve as a basis for policy briefs } \\
\text { - Provide access to information from various applied research studies which can be } \\
\text { replicated in other contexts } \\
\text { - Provide detailed descriptions of traits found in publically available germplasm } \\
\text { - Sources of inspiration and innovative ideas } \\
\text { - Useful for skills development }\end{array}$ \\
\hline Books & $\begin{array}{l}\text { - Provide knowledge enhancement } \\
\text { - Important for training and formal education } \\
\text { - Sources of bibliographic references }\end{array}$ \\
\hline
\end{tabular}




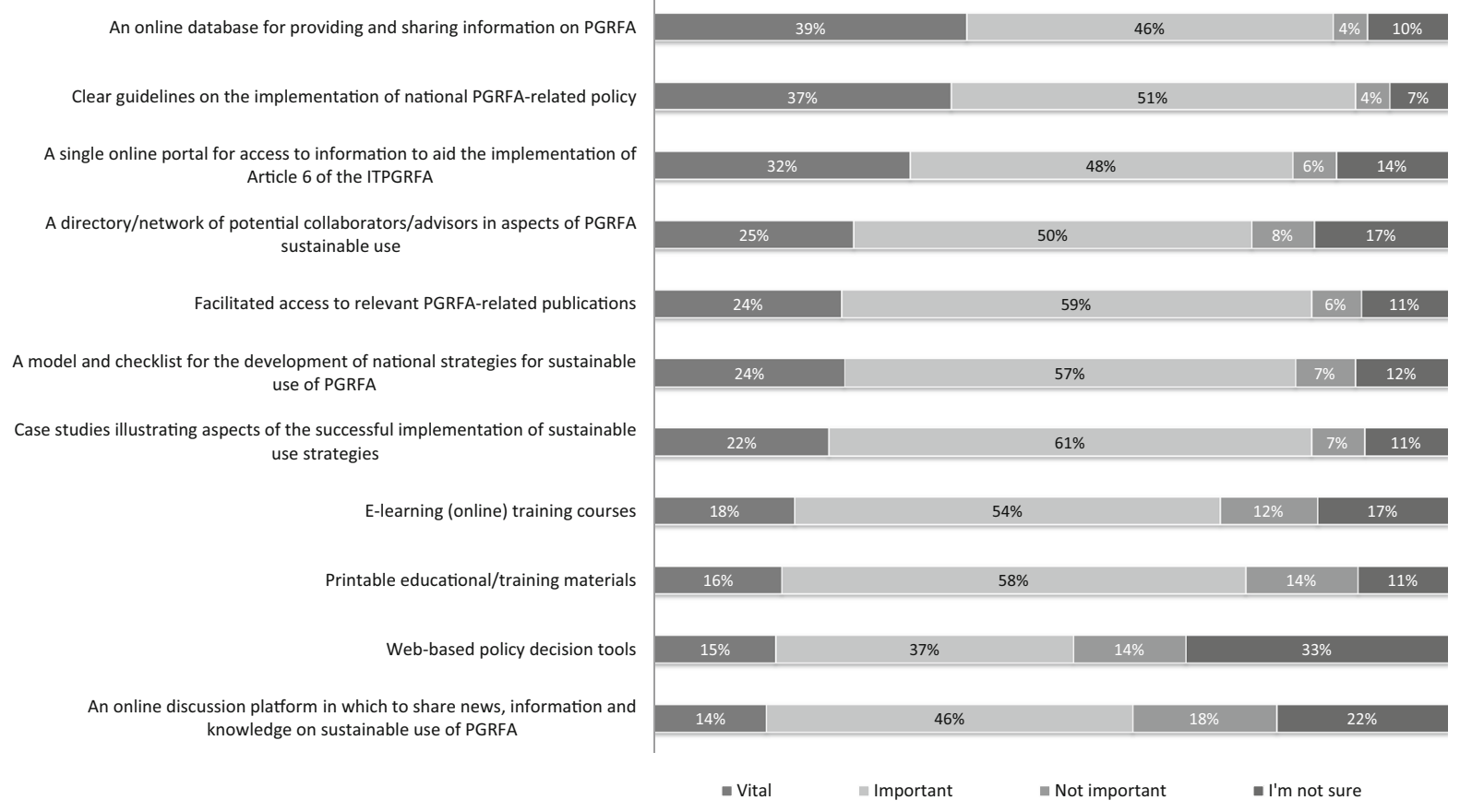

Fig. 13 Relative importance of specific tools and resources to assist countries in implementing PGRFA sustainable use strategies $(\mathrm{n}=254)$

information on potential collaborators for crop improvement programmes. Paucity of characterization and evaluation data was reported as a major constraint to germplasm use in the first Report on the State of the World's Plant Genetic Resources for Food and Agriculture (FAO 1997) and in the Second Report (FAO 2010, p. 96) it was noted that countries were "virtually unanimous in suggesting that one of the most significant obstacles for greater use of PGRFA is the lack of adequate characterization and evaluation data and the capacity to generate and manage such data". A survey of the use of crop wild relatives in crop improvement programmes also revealed that the dearth of phenotypic and genotypic data is the most significant barrier to their use (Dempewolf et al. 2017). Efforts are currently being made to increase the availability of characterization and evaluation data through initiatives such as Divseek ${ }^{29}$ and EURISCO, ${ }^{30}$ but much work needs to be done to characterize existing germplasm collections to increase their value

\footnotetext{
29 www.divseek.org.

${ }^{30} \mathrm{http}$ ///eurisco.ipk-gatersleben.de/.
}

as sources of genetic diversity for crop improvement. Sequencing (McCouch et al. 2013) and wider use of 'omics' and predictive characterization techniques (Maxted et al. 2016) have been proposed as fast-track solutions.

The majority ( $84 \%$ ) of respondents indicated a need for training, institutional strengthening, or both, in order for stakeholders to effectively implement the sustainable use provisions of the Treaty, and the results show that capacity building is needed in all areas of the PGRFA sustainable use spectrum. Analyses of capacity building needs across stakeholder groups and between and within regions reveals general agreement on needs across groups and between and within regions, although some variations were detected which may be useful to inform policy-makers, managers, trainers and other relevant stakeholders in those regions, as well as those involved in planning, funding and provision of capacity building in international organizations. The survey results have also confirmed that a wide range of types of resources are important to support the activities of stakeholders, and critically, why specific types of resources are useful and practical, as well as which additional resources are needed. All options for specific 
tools and resources to assist countries in implementing PGRFA sustainable use strategies presented in the survey are considered vital by a minimum of 14-39\% of respondents and important by at least $37-61 \%$. Respondents were also requested to provide examples of resources they require to support their work in sustainable use of PGRFA, stating the topic, type of resource and why it is needed. These topics can be broadly classified into those relating to: (a) sustainable use policy; (b) characterization and evaluation; (c) PGRFA conservation techniques; (d) adding value to and sustaining the use of landraces/farmers' varieties; (e) crop improvement; (f) access to PGRFA material and associated information; (g) seed systems; and (h) communication and awareness.

Many of the factors impinging on effective sustainable use of PGRFA uncovered in this survey were not previously unknown to the PGRFA stakeholder community but this is the first investigation that has taken a systematic view of the whole PGRFA use system and involved the global community across the full range of stakeholder groups. The research has served to clarify the major bottlenecks in the PGRFA use system which can be broadly categorized as: (a) missing policies or ineffective implementation of existing policies to support sustainable use across the whole system (i.e., from plant genetic diversity conservation to product marketing); (b) lack of human and institutional capacity (technical, technological and financial) in all areas of the PGRFA use system; and (c) insufficient commitment to and long-term financial support for plant genetic diversity conservation in situ (including on-farm) and ex situ, for characterization and pre-breeding, as well as for associated information management and visibility. As highlighted by FAO (2010), the actions needed to improve the PGRFA use system are complex and wide-ranging but it is essential that these bottlenecks are addressed to meet the food supply demands of the increasing human population and the impacts of climate change on food production. Ultimately, these issues need to be addressed at national level, but a regional approach may also be relevant and of course, global organizations and bodies have important roles to play in providing leadership, guidance and coordination.

Notably, recognizing the substantial constraints impacting sustainable use of PGRFA in Europe,
Frese et al. (2014a, 2016a) undertook a study involving five European stakeholder groups: gene banks, public research institutes, plant breeders, NGOs and governments. The authors concluded (Frese et al. 2014b, 2016b) that the main constraints to the sustainable use of PGRFA in Europe are due to: (a) the absence of an organizational, technical and information infrastructure that supports the implementation of conservation actions and meets the needs of the user community; (b) lack of a specific unifying European regulation for PGRFA conservation and sustainable use; and (c) insufficient funding for PGRFA management at national and European levels. They put forward a number of recommendations for actions needed to improve the management and utilization of ex situ conserved PGRFA in Europe, including the establishment of: (a) a technical infrastructure for the organization of PGRFA conservation measures; (b) an information infrastructure to organize the flow of PGRFA conservation and utilization data; and (c) a legal basis for PGRFA conservation and sustainable use in Europe. The authors also highlighted the need for greater financial support to gene banks, long-term crop specific pre-breeding programmes, and a European network of publicprivate partnership programmes for evaluation of PGRFA. As these recommendations relate only to PGRFA conserved ex situ, we would also stress the need for planning and implementing in situ and onfarm networks that are fully integrated with ex situ conservation and sustainable use activities.

Taking into account the outcomes of the current survey and the regional approach taken by Frese et al. (2014a, 2016a), perhaps other regional administrations could undertake reviews of the PGRFA use system to highlight specific needs in their respective regions. Where possible, targeted and coordinated actions within regions would bolster efforts by individual nations and in turn strengthen the global PGRFA use system and support our interdependent world of genetic resource use. Importantly, the stakeholder community needs to work together towards this common goal. Achieving sustainable use of PGRFA involves all actors in the system, including policy-makers, researchers, plant breeders, farmers, seed suppliers, fund-raisers, managers, teachers, trainers and other facilitators. 


\section{Conclusions}

The strong interest in the survey evidenced by the high response rate and comprehensive comments provided is no doubt a reflection of stakeholders' concerns about the need to address the sustainable use of PGRFA, recognizing their critical role in climate change adaptation and food security. The results have confirmed and allowed a clearer understanding of the bottlenecks in the PGRFA use system-the aspects of PGRFA sustainable use that present the greatest challenges and that need to be addressed by the global PGRFA community. They have also enabled a better understanding of the needs of a wide range of interest groups, organizations and individuals regarding the provision of support for their PGRFA sustainable use activities. In particular, there is a critical need to address limitations regarding policy in support of sustainable use activities, capacity building needs, and access to plant genetic material and associated information. The responses of the survey participants reveal a complex array of issues related to these three broadly defined bottlenecks which involve and impact on all PGRFA stakeholders globally. In our interdependent world, these are global issues impacting the plant breeding and agricultural industries, large and small-scale farmers, and ultimately on food and economic security worldwide. The global PGRFA community needs to come together to lobby for policies and long-term funding to support an effective system of PGRFA sustainable use-a system which is fundamental to meeting the challenges of climate change adaptation, food security and biodiversity loss.

Acknowledgements This research was undertaken in the context of the development of a toolbox for sustainable use of PGRFA under the mandate of the Governing Body of the International Treaty on Plant Genetic Resources for Food and Agriculture. Results of the survey were presented to the Governing Body of the Treaty at its Sixth Session in the form of an information document. ${ }^{31}$ The work was funded by the governments of Italy and Switzerland. The authors are grateful to the members of the Ad Hoc Technical Committee on Sustainable Use of PGRFA and colleagues in the AGDT team at FAO for contributions to the design, testing and translation of the survey and to the many respondents who gave up their time to participate, generously providing their invaluable views on the PGRFA use system.

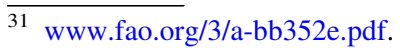

Open Access This article is distributed under the terms of the Creative Commons Attribution 4.0 International License (http:// creativecommons.org/licenses/by/4.0/), which permits unrestricted use, distribution, and reproduction in any medium, provided you give appropriate credit to the original author(s) and the source, provide a link to the Creative Commons license, and indicate if changes were made.

\section{References}

Challinor AJ, Watson J, Lobell DB, Howden SM, Smith DR, Chhetri N (2014) A meta-analysis of crop yield under climate change and adaptation. Nat Clim Change 4:287-291. doi: $10.1038 /$ nclimate 2153

Dempewolf H, Baute G, Anderson J, Kilian B, Smith C, Guarino L (2017) Past and future use of wild relatives in crop breeding. Crop Sci 57:1-13. doi:10.2135/cropsci2016.10. 0885

FAO (1997) The state of the world's plant genetic resources for food and agriculture. Food and Agriculture Organization of the United Nations, Rome. http://www.fao.org/agriculture/ crops/thematic-sitemap/theme/seeds-pgr/sow/en/. Accessed 22 March 2017

FAO (2008) Climate change and biodiversity for food and agriculture. Food and Agriculture Organization of the United Nations, Rome. www.fao.org/uploads/media/FAO_ 2008a_climate_change_and_biodiversity_02.pdf. Accessed 15 Jan 2017

FAO (2010) The second report on the state of the world's plant genetic resources for food and agriculture. Rome. www. fao.org/agriculture/crops/thematic-sitemap/theme/seeds-pgr/ sow/sow2/en/. Accessed 15 Jan 2017

Frese L, Palmé A, Kik C (2014a) On the sustainable use and conservation of plant genetic resources in Europe. Report from Work Package 5 'Engaging the user community' of the PGR Secure project 'Novel characterization of crop wild relative and landrace resources as a basis for improved crop breeding'. www.nordgen.org/ngdoc/plants/Samarbeten_ och_natverk/PGR_secure_workshop2013/Final\%20report/ On_the_sustainable_use_and_conservation_of_PGR_in_ Europe_Sept2014.pdf. Accessed 08 Jan 2017

Frese L, Palmé A, Bülow L, Kik C (2014b) Towards a European Plant Germplasm System: the third way. www.nordgen. org/ngdoc/plants/Samarbeten_och_natverk/PGR_secure_ workshop2013/TowardsEuropeanPlantGermplasmSystem_ policyPaper.pdf. Accessed 08 Jan 2017

Frese L, Palmé A, Neuhaus G, Bülow L, Maxted N, Poulsen G, Kik C (2016a) On the conservation and sustainable use of plant genetic resources in Europe: a stakeholder analysis. In: Maxted N, Ford-Lloyd BV, Dulloo ME (eds) Enhancing crop genepool use: capturing wild relative and landrace diversity for crop improvement. CAB International, Wallingford, pp 388-400

Frese L, Palmé A, Bülow L, Kik C (2016b) Towards an improved European Plant Germplasm System. In: Maxted N, Ford-Lloyd BV, Dulloo ME (eds) Enhancing crop genepool use: capturing wild relative and landrace 
diversity for crop improvement. CAB International, Wallingford, pp 401-411

Green N (2008) Conserving traditional UK crops. The Plantsman 7(4):235-239

Green N, Campbell G, Tulloch R, Scholten M (2009) Scottish Landrace Protection Scheme. In: Veteläinen M, Negri V, Maxted N (eds) European landraces: on farm conservation, management and use. Bioversity Technical Bulletin No. 15. Bioversity International, Rome, pp 233-243

Grum M, Gyasi EA, Osei C, Kranjac-Berisavljevic G (2008) Evaluation of best practices for landrace conservation: farmer evaluation. Bioversity International, Rome, p 20

Guarino L, Lobell DB (2011) A walk on the wild side. Nat Clim 1:374-375. doi:10.1038/nclimate 1272

ISSD Ethiopia (2016) BENEFIT-Integrated Seed Sector Development in Ethiopia, 2016-2019: Project summary. Integrated Seed Sector Development in Ethiopia Programme. www. issdethiopia.org/images/benefit_issd\%20ethiopia_project\% 20summary.pdf. Accessed 21 March 2017

Kovats RS, Valentini R, Bouwer LM, Georgopoulou E, Jacob D, Martin E, Rounsevell M, Soussana J-F (2014) Europe. In: Barros VR, Field CB, Dokken DJ, Mastrandrea MD, Mach KJ, Bilir TE, Chatterjee M, Ebi KL, Estrada YO, Genova RC, Girma B, Kissel ES, Levy AN, MacCracken S, Mastrandrea PR, White LL (eds) Climate change 2014: impacts, adaptation, and vulnerability. Part B: regional aspects. Contribution of working group II to the fifth assessment report of the Intergovernmental Panel on Climate Change. Cambridge University Press, Cambridge, United Kingdom and New York, NY, USA, pp 1267-1326

Louwaars NL, de Boef WS, Edeme J (2013) Integrated seed sector development in Africa: a basis for seed policy and law. J Crop Impr 27(2):186-214. doi:10.1080/15427528. 2012.751472

Luck J, Spackmand M, Freemand A, Trebicki P, Griffiths W, Finlay K, Chakraborty S (2011) Climate change and diseases of food crops. Plant Path 60:113-121. doi:10.1111/j. 1365-3059.2010.02414.x

Maxted N, Kell SP, Ford-Lloyd BV, Dulloo ME, Toledo A (2012) Toward the systematic conservation of global crop wild relative diversity. Crop Sci 52(2):774-785. doi:10. 2135/cropsci2011.08.0415

Maxted N, Avagyan A, Frese L, Iriondo JM, Magos Brehm J, Singer A, Kell SP (2015) ECPGR concept for in situ conservation of crop wild relatives in Europe. Wild Species Conservation in Genetic Reserves Working Group, European Cooperative Programme for Plant Genetic Resources. http://www.ecpgr.cgiar.org/fileadmin/templates/ecpgr.org/ upload/WG_UPLOADS_PHASE_IX/WILD_SPECIES/ Concept_for_in_situ_conservation_of_CWR_in_Europe. pdf Accessed 24 April 2017

Maxted N, Amri A, Castañeda-Álvarez NP, Dias S, Dulloo ME, Fielder H, Ford-Lloyd BV, Iriondo JM, Magos Brehm J,
Nilsen L-B, Thormann I, Vincent H, Kell SP (2016) Joining up the dots: a systematic perspective of crop wild relative conservation and use. In: Maxted N, Ford-Lloyd BV, Dulloo ME (eds) Enhancing crop genepool use: capturing wild relative and landrace diversity for crop improvement. CAB International, Wallingford, pp 87-124

McCouch S et al (2013) Feeding the future. Nature 499:23-24. doi:10.1038/499023a

Noble I, Huq S, Anokhin Y, Carmin J, Goudou D, Lansigan F, Osman-Elasha B, Villamizar A (2014) Adaptation needs and options. In: Field C, Barros V, Mach K, Mastrandrea M (Lead authors) Climate change 2014: impacts, adaptation, and vulnerability. IPCC working group II contribution to AR5. Part A: global and sectoral aspects. www.ipcc.ch/ report/ar5/wg2/. Accessed 15 Jan 2017

Olesen JE, Trnka M, Kersebaum KC, Skjelvåg AO, Seguin B, Peltonen-Sainio P, Rossi F, Kozyra J, Micale F (2011) Impacts and adaptation of European crop production systems to climate change. Eur J Agron 34(2):96-112. doi:10. 1016/j.eja.2010.11.003

Phillips J, Asdal Å, Magos Brehm J, Rasmussen M, Maxted N (2016) In situ and ex situ diversity analysis of priority crop wild relatives in Norway. Div and Distrib 22(11):11121126. doi:10.1111/ddi. 12470

Pinheiro de Carvalho MÂA, Nóbrega H, Freitas G, Fontinha S, Frese L (2012) Towards the establishment of a genetic reserve for Beta patula Aiton. In: Maxted N, Dulloo ME, Ford-Lloyd BV, Frese L, Iriondo JM, Pinheiro de Carvalho MAA (eds) Agrobiodiversity conservation: securing the diversity of crop wild relatives and landraces. CAB International, Wallingford, pp 333-354

Rötter RP, Palosuo T, Pirttioja NK, Dubrovski M, Salo T, Fronzek S, Aikasalo R, Trnka M, Ristolainen A, Carter T (2011) What would happen to barley production in Finland if global warming exceeded $4{ }^{\circ} \mathrm{C}$ ? A model-based assessment. Eur J Agron 35(4):205-214. doi:10.1016/j.eja.2011. 06.003

Sperling L, McGuire S (2010) Understanding and strengthening informal seed markets. Expl Agric 46(2):119-136. doi:10. 1017/S0014479709991074

Sperling L, McGuire S (2016) Seed systems smallholder farmers use. Food Sec 8:179-195. doi:10.1007/s12571-0150528-8

Ventrella D, Charfeddine M, Bindi M (2012) Agronomic adaptation strategies under climate change for winter durum wheat and tomato in southern Italy: irrigation and nitrogen fertilization. Reg Environ Change 12(3):407-419. doi:10.1007/s10113-011-0256-3

Vorley B, Cotula L, Chan M-K (2012) Tipping the balance: Policies to shape agricultural investments and markets in favour of small-scale farmers. Oxfam International and the International Institute for Environment and Development, Oxford 